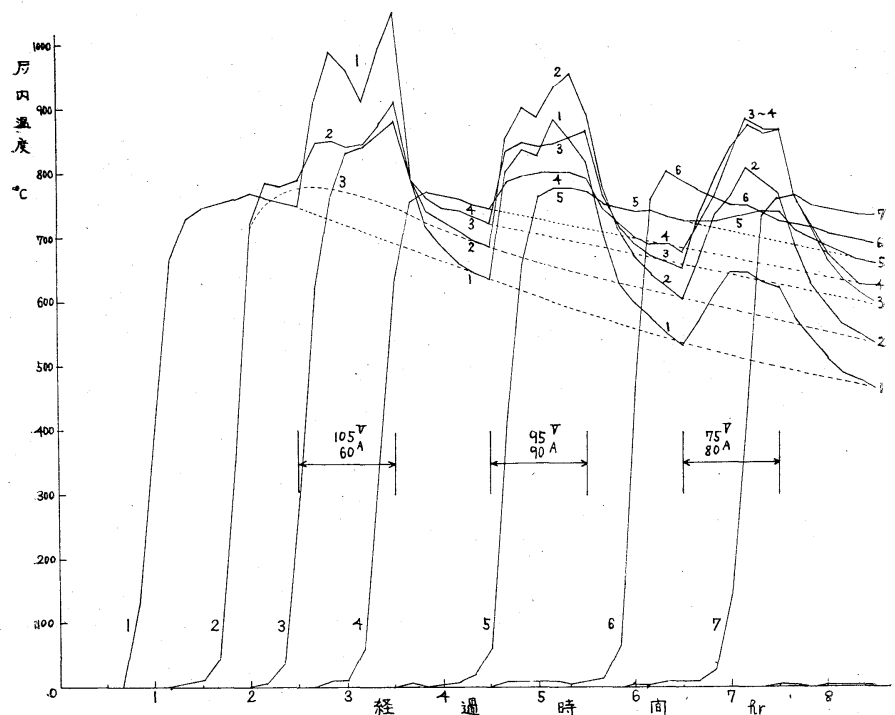

第 4 図経渦時間と層内温度（第 5 回実験）

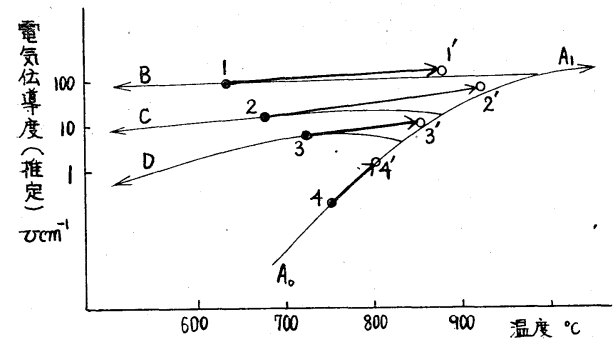

$1,2,3,4:$ 经過時間 4:30 打打る温度測定孔番号 $1^{\prime}, 2^{\prime}, 3^{\prime}, 4^{\prime}$ : 経過時間 5:10 亿和外る温度测定孔番号 第 5 図温度逆転現象説明図
と，それぞれわずかな電気伝導度の差が電 流密度に相違を生じさや経過時間 $5: 10$ の 状態 $\left(1^{\prime}, 2^{\prime}, 3^{\prime}, 4^{\prime}\right)$ をつくるものと考えて いる。

\section{6. 結 論}

燃焼切羽面に及ぼす電気エネルギーの影 響の有無を判明すべく第 1 回実験から第 回実験に亘つて試験老行なつた結果次の結 論を得た。

（1） $5 \%$ の危険率で, 送気量の增大予 よび電気エネルギーは有用ガス成分を堌加 させるといいうる。

(2) 電流は，朔流式で，主汇酸化率よ り当還元率中を通過する。

（3）消費電力よりも電気エネルギーに よる生成ガス保有熱増加分の方が小さく， 石炭 $1 \mathrm{~kg}$ 当り消費電力の約 $50 \%$ しか增 加しなかつた。

（4）（1）のように送気量の增大によつ て有用ガス成分を增加させることも可能で 昰るが石若の地下ガス化に和ける特殊条件を考え合せる と, 現在でば(3) の如く不経済ではあるが今後も本研究 を続行し新しい工法として開発すべきであること。

今後に残された問題点として

(1) 電気ニネルギーが単に熱として作用するのかまた は電気化学的作用するのか。

(2) 反応速度論的考察を行ない得る装置にすること。

（3）消費電力を少なくし，な括かつ有用生成がス成分 を増加できる工法をみつけること。

扣わりに, 有效な御助言をいただいた住友石炭北海道 技術研究所知野貞三先生はじめ同所の方々に深く謝意を 表する。

\title{
403 石炭の地下ガス化に関する基礎的研究
}

\section{電解質溶液が石炭の電気抵抗に及ぼす影響}

$\begin{array}{rrrrr}\text { 九州大学生産科学研究所教授・工博 } & \text { ○江 } & \text { 淵 } & \text { 藤 } & \text { 彦 } \\ \text { 九州大学生産科学研究所助手 } & \text { 河 } & \text { 野 } & \text { 静 } & \text { 头 } \\ \text { 九州大学生産科学研究所助手 } & \text { 石 } & \text { 蔵 } & \text { 利 } & \text { 昭 }\end{array}$

\section{1. まえがき}

現在, 当研究所で研究を進めている電流乾留による石 炭の地下ガス化方式は，従来の然焼方式等によるガス化 化比し，ガス化効率，成分，作業性など，あらゆる面で 利点が多いが，この場合，ただ問題となるのは石炭が電 気の不良尊体であり，その抵抗が $10^{8 \sim 9} \Omega \mathrm{cm}$ の非常に 大きな值であるため, 実際に拈いては高電圧, 大電流を 利用しなければならず，相当の電力を要するということ が欠点である。

しかし，今日までの試験結果によると，石炭のこの大 きな抵抗も電流乾留過程の初期だけのものであつて, 乾 留が進导につれて石炭の電気抵抗は急激に減少する。

そこで当面考えられねばならないのが，この乾留過程
に新ける初期の電気抵抗をいかにして低下させるかとい うことである。

ここで, 電解質溶液等を利用して石炭の見掛けの電気 抵抗の減少法についての試験を進めているので, その結 果について報告市る。

本試験はつぎのような諸点を明らかにする目的で行な つたものである。

i ）電解質溶液の注入によつて石炭の電気抵抗をどの 程度まで低隇できるか。

ii）石炭の電気抵抗低下済として,どのような電解䝷 またはその濃度が効果的か。

iii）実用に当つて, 電解質溶液の石炭にたい寸る注大 状態, むたは注大の作業性, あるいは経済性などの点か ら検討してどのような電解質が実用性が高いか，などの 


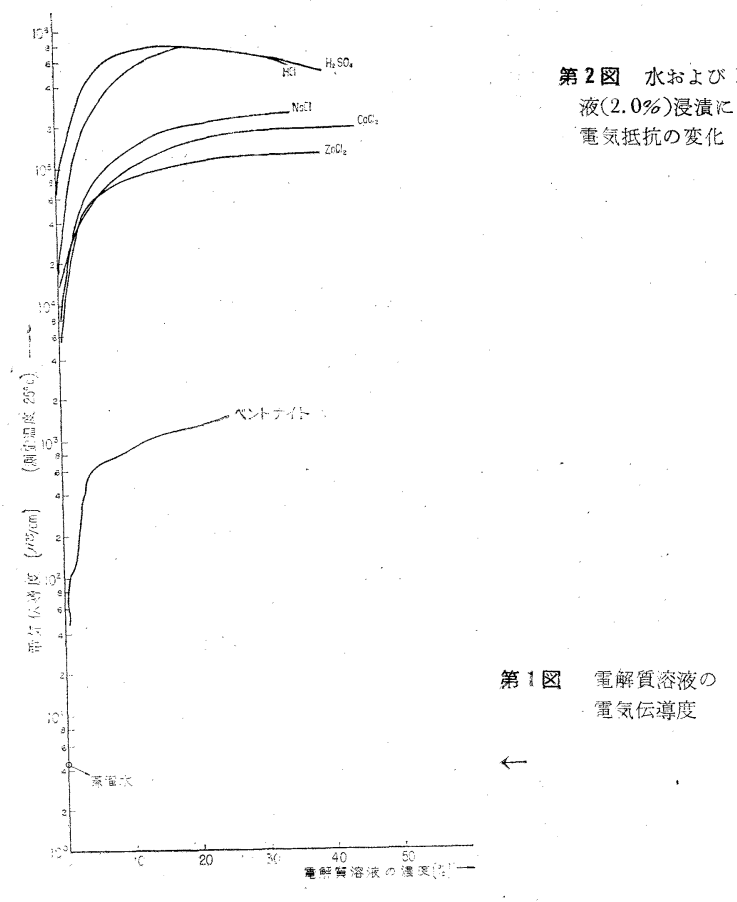

点である。

\section{2. 実 験 概 要}

(1) 電解質 試虞に使用した電解質法 $\mathrm{CaCl}_{2}, \mathrm{KCl}$, $\mathrm{NaCl}, \mathrm{NaOH}, \mathrm{KOH}, \mathrm{ZnCl}_{2}, \mathrm{CO}\left(\mathrm{NH}_{2}\right)_{2}$ 岕よび $\mathrm{H}_{2} \mathrm{SO}_{4}$, $\mathrm{HCl}$ などであり,これらの水溶液の謴度と電気伝尊性を しらべた。第 1 図にその結果を示す。

（2）石炭試料 志免炭の $150 \sim 250$ meshで，これに 各電解質溶液を種々の割合で含浸させ，これらの電気抵 抗を測定した。な捕，一部塊岸も使用したが，これは志 免炭, 大島炭, 三池炭, 田川無煙炭などで, 孔吵, 炭化 䧛の異なる代表的なるのを選んだ。そしてこれを（3×3 $\times 3) \mathrm{cm}$ の大きさ纪成型し, 上記の各電解質溶液に一定 時間浸潰し, 浸漬後の吸水量と電気抵抗の関係苯しらべ た。

（3）試験法 電解質溶液の䉓気伝導度測定は, 東再 電波工業の CM-IDB 型数字式電気伝導度計安使用儿 た。溶液の電気伝導度は气の濃度によつて変化すること は勿論であるが，液温にも敏感である。今回の試験条件 は各溶液々も, 液温 $25^{\circ} \mathrm{C}$ で測定した。

つぎは，溶液を粉炭に含浸させて，乞の電気抵抗を測 定するのであるが，一定量の石炭試料そ溶液をがラス容

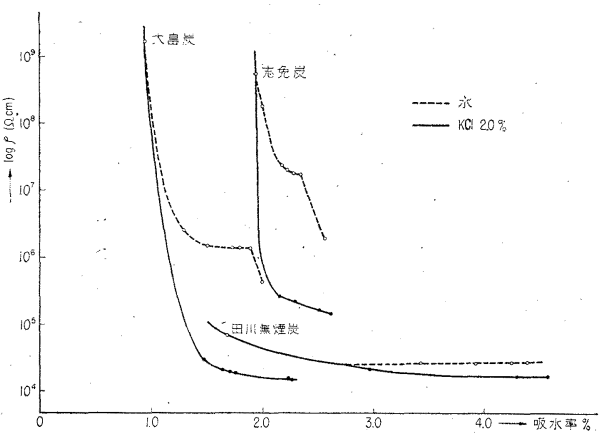

器に取り,十分䚌拌して,溶液を粉炭にむらなく含浸させ る。この試料について電気抵抗を測定するのであるが, 電気抵抗測定装置は, 絶縁用合成樹脂で製作されたシり ンダーに試料を装媜し，Joseph D. Davis らがューク ス粉の電気抵抗を測定したと同様な方法により，2 軸圧 縮試験機（スクリニージャッキ型）にて試料を加圧し， 均質にして，その電気抵抗を測定した。

\section{3. 実験結果および検討}

塊炭についての試験結果を第 2 図に示した。な拈, こ の塊岸の試験法は,さきに述べた $3 \mathrm{~cm}^{2}$ 糎危の試料の対面 飞電導性接着剤（エポキシ樹脂に銀粉混入）を塗布しこ れを電極とし，浸清後の試料の電気抵抗を測定した。測 定値はつぎの式によつて比抵抗値に換算した。

$$
\begin{aligned}
\gamma=\frac{\rho l}{S} & \\
\gamma & : \text { 電気抵抗 }(\Omega) \\
\rho & : \text { 比抵抗 }(\Omega-\mathrm{cm}) \\
l & : \text { 長さ }(\mathrm{cm}) \\
S & : \text { 断面積 }\left(\mathrm{cm}^{2}\right)
\end{aligned}
$$

第 2 図は, 水扰上び $\mathrm{KCl} 2 \%$ 溶液に浸漬した場合の吸 水率々電気抵抗の関係であるが，本図に示されるように 石炭 (歴青炭) の電気抵抗は $10^{9} \Omega-\mathrm{cm}$ 前後の值である が，吸水によつて急激な低下を示す。これに反し下，無 煙炭は元来その抵抗は小さいが，吸水の影響もまた少な い。

また上の石炭試料を $\mathrm{KCl} 2 \%$ 液 $(30.9 \Omega-\mathrm{cm})$ 飞浸し た場合は水道水 $(1,660 \Omega-\mathrm{cm})$ に浸した場合に比し, 各 試料共その電気抵抗の低下率がよく, とくに潛青炭の場 合はその低隇率が著しく。もとと $10^{9} \Omega-\mathrm{cm}$ の石炭 が $\mathrm{KCl} 2 \%$ 液浸漬によつて $10^{4} \Omega-\mathrm{cm}$ 飞低下すること が明らかとなつた。

これらの事実をさらに詳細に, 采統的に究めるため, 均質な粉炭を使用して同様な試験を行なつている。

\title{
404 住友赤平礦における注水発破採炭について
}

\author{
住友石炭釷業株式会社䓇平沰業所岡町昌哉
}

\section{1. 注水発破が問題となつた理由}

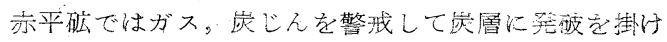
ない原則㤂岕つた。
しかしながら薄層で堅緻，かつ断層玉石が多い炭層 (䍗層の一層を採掘した後)また厚層でも急傾斜で堅く断 層玉石の多い場合には機珹化困難で，ピック作業を補助 する乎段として発破の必要性を惹起した。このため炭壁 